\title{
REVIZIJA FINANCIRANJA SPORTA - HORIZONTALNA REVIZIJA GRADOVI ZAGREB I BEČ
}

\author{
Biljana Kršić, Ivana Zovko, Indira Čizmić* \\ Gradski kontrolni ured, Šubićeva 38, Zagreb, Hrvatska
}

\begin{abstract}
Apstrakt:
Gradski kontrolni ured Grada Zagreba i Kontrolni ured Grada Beča obavili su horizontalnu Reviziju financiranja sporta radi procjene uspostavljenog sustava unutarnjih kontrola, davanja stručnog mišljenja i preporuka za unapređenje sustava. Revizija je obavljena po metodologiji za obavljanje unutarnje revizije Ministarstva financija. Zajedničke karakteristike procesa financiranja sporta u Zagrebu i Beču su: procedure i pravila za dodjelu sredstava za provođenje sportskih programa, sustav unutarnjih kontrola kojim se osigurava transparentna raspodjela sredstava, dokumentirane faze raspodjele sredstava. U Gradu Zagrebu postoji mogućnost za unapređenje sustava unutarnjih kontrola u procesima raspodjele sredstava za velike sportske priredbe i praćenja namjenskog korištenja sredstava za realizaciju programa sporta. Nositeljima revidiranog procesa predloženo je propisivanje kriterija za raspodjelu sredstava za velike sportske priredbe i implementiranje jedinstvenog informatičkog rješenja za proces raspodjele i kontrole namjenskog korištenja sredstava za provedbu programa javnih.
\end{abstract}

\author{
Ključne reči: \\ sustav unutarnjih kontrola, \\ javne potrebe u sportu, \\ namjensko korištenje proračunskih \\ sredstava.
}

\section{UVOD}

Metodologija, standardi, odnosi i odgovornosti te nadležnosti korisnika proračuna u provedbi sustava unutarnjih financijskih kontrola u javnom sektoru Republike Hrvatske propisani su 2005. godine Zakonom o sustavu unutarnjih financijskih kontrola u javnom sektoru. Novi Zakon o sustavu unutarnjih kontrola u javnom sektoru donesen je sredinom 2015. godine. Sustav unutarnjih financijskih kontrola obuhvaća financijsko upravljanje i kontrole te unutarnju reviziju. Svrha uspostave financijskog upravljanja i kontrola je unaprjeđenje uspostavljenih kontrolnih mehanizama temeljem kojih čelnici korisnika proračuna donose odluke o korištenju proračunskih sredstava radi postizanja općih ciljeva. U javnoj upravi Republike Hrvatske sustav unutarnjih financijskih kontrola u praksi se provodi kroz tri elementa: financijsko upravljanje i kontrole, funkcionalno neovisnu unutarnju reviziju i Središnju harmonizacijsku jedinicu Ministarstva financija, koja ima ulogu koordinatora aktivnosti korisnika proračuna pri uspostavi i razvoju sustava unutarnjih financijskih kontrola za javni sektor.

Proces usklađivanja sustava unutarnjih financijskih kontrola s međunarodno priznatim praksama javnog upravljanja i prema pravnoj stečevini Europske zajednice u Gradu Zagrebu pokrenut je u lipnju 2005. godine ustrojavanjem Gradskog kontrolnog ureda nadležnog za obavljanje poslova unutarnje revizije gradskih upravnih tijela, tijela Grada Zagreba, tijela mjesne samouprave i proračunskih korisnika.
Budući da je 2005. godine unutarnja revizija kao profesija u javnom sektoru bila „novost“ na svim razinama u Republici Hrvatskoj, radi afirmiranja unutarnjih revizora u Gradu Zagrebu, Gradski kontrolni ured (koji je ustrojen po modelu koji funkcionira u Gradu Beču) je 2005. godine počeo suradnju s Kontrolnim uredom Grada Beča. Ustrojstvene i funkcionalne sličnosti gradske uprave Zagreba i Beča, zajednički interesi i spremnost na usvajanje „dobre prakse“ rezultirale su desetogodišnjom suradnjom i obavljanjem dvije horizontalne revizije (Vođenje državnih matica -2013. godine i Financiranje sporta - 2014. godine).

\section{REZULTATI I DISKUSIJA}

Revizija financiranja sporta u Gradu Zagrebu obavljena je kao horizontalna revizija u suradnji s unutarnjim revizorima Kontrolnog ureda Grada Beča (Gradskog revizorskog suda) s ciljem procjene sustava unutarnjih kontrola u procesu dodjele proračunskih sredstava za financiranje sporta u Gradu Zagrebu i Gradu Beču. Iz proračuna Grada Zagreba kroz javne potpore u sportu financiraju se programi, aktivnosti i djelatnosti od značenja za lokalnu zajednicu. Revizija je obavljena po metodologiji Ministarstva financija koju su dužni primjenjivati unutarnji revizori u javnom sektoru. Cilj revizije i poslovni cilj procesa bio je procijeniti primjenu i djelotvornost sustava unutarnjih kontrola u procesu financiranja sporta u Gradu Zagrebu koji treba doprinijeti razvoju kvalitete sporta. Proces financiranja sporta testiran je kroz kontrolne ciljeve 
i glavne rizike procesa. Revizija je obuhvatila proces financiranja sporta od izrade Programa javnih potreba u sportu do izvještavanja o realizaciji Programa. Testiranjem su obuhvaćeni zahtjevi sportskih udruga za dodjelu sredstava, predmeti potpora vrhunskom sportu, predmeti vezani uz male i velike sportske priredbe. Analizirano je organizacijsko ustrojstvo i suradnja Sportske zajednice Grada Zagreba te Gradskog ureda za obrazovanje, kulturu i sport u pripremi i provođenju sportskih aktivnosti/programa od interesa za Grad Zagreb, pomoću upitnika utvrđene su aktivnosti u revidiranom procesu u Gradu Zagrebu i Gradu Beču. Obavljeni su razgovori s rukovodećom i operativnom razinom službenika.

Opis procesa: Grad Zagreb utvrđuje javne potrebe u sportu i za njihovo ostvarivanje osigurava financijska sredstva u skladu s propisima. Radi ostvarivanja zajedničkih interesa u sportu u Gradu Zagrebu je osnovana je Sportska zajednica Grada Zagreba u kojoj uglavnom rade bivši vrhunski sportaši. Javne potrebe u sportu Grada Zagreba utvrđuju se Programom javnih potreba u sportu Grada Zagreba koji donosi Gradska skupština Grada Zagreba. U Programu su propisana mjerila i kriteriji za financiranje sportskih programa. Osnovni ciljevi Programa su: ulaganje sredstava u razvoj mladih sportaša, unapređenje vrhunske sportske kvalitete i poticanje uključivanja u sport što većeg broja građana, osobito djece i mladeži. Plan sredstava za sufinanciranje Programa javnih potreba u sportu Grada Zagreba donosi gradonačelnik. Namjensko korištenje sredstava prate Sportska zajednica Grada Zagreba pomoću aplikativnog sustava i Gradski ured za obrazovanje, kulturu i sport kroz izvješća koja dostavljaju korisnici sredstava. Polugodišnja i godišnja izvješća o izvršenju Programa javnih potreba u sportu i sredstvima osiguranim izvan Programa dostavljaju se na usvajanje Gradskoj skupštini Grada Zagreba. U razdoblju 2010. - 2013. godine iz proračuna Grada Zagreba je za financiranje sporta na godišnjoj razini izdvajano cca 40.000.000,00 eura (4,5\% sredstava gradskog proračuna).

U Gradu Beču sport se financira iz proračunskih sredstava te prihoda ostvarenih od doprinosa za potpore u sportu. Naime, prema bečkom zakonodavstvu, $10 \%$ prihoda od prodaje ulaznica za sportske priredbe uplaćuje se u gradski proračun i koristi za održavanje sportskih građevina te poticanje vrhunskog i masovnog sporta. Pored toga, sport se financira neizravnim potporama što podrazumijeva iznajmljivanje ili davanje u zakup više od 3,3 milijuna $\mathrm{m}^{2}$ sportskih površina, 520 gimnastičkih dvorana, 18 sportskih dvorana i terena za sport za mlade po cijenama ispod tržišne vrijednosti. U razdoblju 2010. - 2013. godine iz proračuna Grada Beča je za financiranje sporta na godišnjoj razini izdvajano cca $75.000 .000,00$ eura ( $0,4 \%$ sredstava gradskog proračuna).

\section{NALAZI I PREPORUKE REVIZORA}

\section{Kontrolni cilj: Osigurati organizacijske pretpostavke za funkcioniranje sporta}

U Republici Hrvatskoj za organizaciju i realizaciju javnih potpora u sportu i održivi razvoj sporta nadležna je državna i lokalna razina (općine, gradovi, županije i nadležno ministarstvo). Uloga županija, gradova i općina u financiranju sporta propisana je: Zakonom o lokalnoj i područnoj (regionalnoj) samoupravi, Zakonom o sportu i Zakonom o udrugama.

U Republici Austriji, na temelju federalnog ustroja države, sredstva za potpore u sportu dodjeljuju Savezna država,
Savezne pokrajine i općine. Pored navedenog, državne i nedržavne ustanove također dodjeljuju sredstva za potpore u sportu. Financiranje sporta sa savezne razine provodi se prema načelima Saveznog zakona o potporama u sportu. Okvirni uvjeti za dodjeljivanje potpora u gradu Beču definirani su Pokrajinskim zakonom o sportu za Beč i Zakonom Grada Beča o doprinosima za potpore u sportu.

\section{Nalaz 1. Nadležnost za sustav sporta u Gradu Zagrebu}

Gradski ured za obrazovanje, kulturu i sport, između ostalog, nadležan je izradu kriterija za financiranje programa djelatnosti sporta, izradu gradskog programa javnih potreba u sportu, praćenje i nadzor izvršenja programa. Sportska zajednica Grada Zagreba kroz djelatnosti objedinjuje i organizira sustav sporta kojeg čine 73 gradska sportska saveza, više od 880 sportskih klubova i oko 38.000 sportaša registriranih pri gradskim savezima. Propisan je Pravilnik o unutarnjem ustrojstvu Ureda i donesen je Statut Sportske zajednice. Revizijom je utvrđeno da je opisan poslovni proces financiranja sporta te da su podjelom funkcija u procesima uspostavljene kontrole razdvajanja dužnosti i ovlasti (jasno je definirano tko odobrava i kontrolira iznos sredstva te tko isplaćuje sredstva).

\section{Nalaz 1. Nadležnost za sustav sporta u Gradu Beču}

Središnja služba za financiranje sporta u Beču je Magistratski odjel 51 - Ured za sport. Sukladno Pokrajinskom zakonu o sportu, ustrojena je Pokrajinska sportska organizacija Beča kojom upravlja Magistratski odjel 51. Pokrajinsku sportsku organizaciju čine sve udruge i savezi sa sjedištem u Beču čija je svrha promicanje sportskih aktivnosti. Osnovan je Bečki sportski fond koji se financira iz doprinosa za financiranje sporta i njime upravlja Magistratski odjel 51. Donesen je organizacijski priručnik u kojem su opisane nadležnosti i procesi povezani s potporama u sportu. Jasno su propisane odgovornosti između osoba koje pregledavaju potpunost zahtjeva za dodjelom potpore, isplatu i kontrolu namjenskog utroška sredstava.

Mišljenje: Uspostavljena procedura financiranja javnih potpora u sportu na lokalnoj, regionalnoj i državnoj razini adekvatan je preduvjet za organizaciju i funkcioniranje sporta. Propisi kojima je uređen sustav sporta i sportske djelatnosti, nadležnost utvrđivanja javnih potreba u sportu i njihovo financiranje te uspostavljeni organizacijski ustroj omogućavaju razvoj, funkcioniranje i praćenje rezultata u sportu. Revizija je potvrdila jasno definirane odgovornosti tijela uključenih u proces financiranja sporta u Beču i Zagrebu. Opisi poslovnih procesa osiguravaju lakše razumijevanje sustava i podloga su za kontinuirano provođenje aktivnosti radi unapređenja organizacije i realizacije sustava javnih potpora u sportu u svrhu detektiranja realnih potreba građana $i$ aktivnog uključivanja u programe svih dobnih skupina. Analizirajući visinu udjela sredstava u proračunu Beča i Zagreba namijenjenih javnim potporama u sportu, može se zaključiti da, unatoč ograničenim financijskim sredstvima, Zagreb izdvaja značajna proračunska sredstva za financiranje sporta. Revidirajući uspostavljeni sustav nadležnosti gradskih upravnih tijela u organizaciji sustava javnih potpora u sportu (Magistarski odjel 51 u Beču i Gradski ured za obrazovanje, kulturu i sport u Zagrebu) i ulogu sportskih organizacija u realizaciji javnih potpora (Pokrajinska sportska organizacija 
u Beču i Sportska zajednica u Gradu Zagrebu) revizijski tim je mišljenja da je, uvažavajući različitost u funkcionalnom i organizacijskom smislu gradova, uspostavljeni sustav nadležnosti istovjetan.

\section{Kontrolni cilj: Osigurati kriterije za donošenje Programa javnih potreba u sportu Grada Zagreba}

\section{Nalaz 2. Kriteriji za dodjelu sredstava za sportske aktivnosti u Gradu Zagrebu}

Program javnih potreba u sportu za 2013. godinu izrađen je na temelju iskazanih potreba sportskih saveza i usklađen je s planiranim proračunskim sredstvima. Program je javno objavljen na web stranicama Grada Zagreba. Propisani su kriteriji temeljem kojih se rangiraju sportovi. Prema značaju i utvrđenom broju bodova sportovi se rangiraju u pet razreda. Nakon rangiranja sportova izrađuje se pregled selekcija sportaša kojom je za svaki sport utvrđen broj klubova, pokazatelj kvalitete sportaša (broj kategoriziranih sportaša od I. do V. kategorije i broj nekategoriziranih sportaša) te broj sportskih škola. U okviru Programa javnih potreba u sportu Grada Zagreba za rangiranje klubova uvažavaju se specifičnosti individualnih sportova u odnosu na momčadske sportove. Programom su propisani kriteriji za financiranje klubova nositelja sportske kvalitete u momčadskim sportovima (rad s mladima, međunarodna i domaća natjecanja). U Programu javnih potreba u sportu Grada Zagreba za 2013. godinu status nositelja kvalitete imala je košarka, rukomet, odbojka, nogomet i vaterpolo.

Iz Gradskog ureda za obrazovanje, kulturu i sport dodjeljuju se potpore vrhunskom sportu i sufinanciraju se velike sportske priredbe značajne za Grad Zagreb (u skladu s raspoloživim proračunskim sredstvima). Za dodjelu sredstava za financiranje velikih sportskih priredbi nisu propisani jasni kriteriji. U 2013. godini za sportske priredbe gradskog značaja osigurano je cca 340.000,00 eura. Radi sprečavanja dvostruke dodjele sredstava sportskim programima Gradski ured za obrazovanje, kulturu i sport i Sportska zajednica Grada Zagreba redovito razmjenjuju podatke o visini dodijeljenih sredstava i informacije važne za provođenje zajedničkih programa sporta.

Nalaz 2. Kriteriji za dodjelu sredstava za sportske aktivnosti u Gradu Beču

Za provedbu programa sportskih aktivnosti Magistratski odjel 51 je izradio Smjernice za sufinanciranje sportskih objekata, sportskih priredaba i ostalo sufinanciranje sporta. Smjernice su javno objavljene. U okviru izravnih potpora u sportu Pokrajinsko sportsko vijeće donijelo je odluke o sufinanciranju sportskih objekata kroz program kojim Grad Beč odobrava podnositelju zahtjeva financijsku potporu za investicije u sportsku infrastrukturu i sufinanciranje značajnih sportskih događaja (primjerice za kupnju dresova ili opreme). Osim navedenih programa, u Gradu Beču se sufinanciraju sportski projekti, krovne organizacije, specijalizirane organizacije, Bečki nogometni savez, vrhunski sport, natjecateljski sport, masovni sport, razvoj djece u nogometu i razvoj djece u drugim sportovima.

U Smjernicama o sufinanciranju propisani su kriteriji temeljem kojih se ocjenjuje svaki pojedinačni zahtjev. Za- htjev se podnosi na standardiziranom obrascu elektroničkim putem ili poštom. Podnositelj zahtjeva mora biti tijelo sa sjedištem u Beču čija je djelatnost neprofitna i usmjerena isključivo na izvedbu sporta koji je u Beču priznat, te koje nije u postupku stečaja. Uz zahtjev podnositelj prilaže i financijski plan koji sadrži popis svih planiranih prihoda, uključujući financijska sredstva koja prima od drugih organizacija. Na taj način je omogućeno da se identificiraju višestruke potpore ukoliko postoje. Kontrolu potpunosti dokumentacije obavlja Magistratski odjela 51 - Ured za sport, a odluku o dodjeli sredstava donosi Gradska skupština Grada Beča. Svi odobreni i odbijeni zahtjevi javno su dostupni.

\section{Nalaz 3. Proces ugovaranja u Gradu Zagrebu}

Gradski ured za obrazovanje, kulturu i sport zaključuje ugovore za sredstva dodijeljena za provođenje velikih sportskih priredbi, poticanje vrhunskog sporta, održavanje sportskih objekata te prilikom dodjele neraspoređenih sredstava. U ugovorima je propisana obveza podnošenja vjerodostojne dokumentacije kojom se potvrđuje namjensko korištenje sredstava i obveza povrata sredstava u slučaju nenamjenskog korištenja. Sportska zajednica Grada Zagreba ne sklapa ugovore već klubovima i savezima isplaćuje sredstva u skladu s Planom sredstava za sufinanciranje Programa javnih potreba u sportu.

\section{Nalaz 3. Proces ugovaranja u Gradu Beču}

U Gradu Beču se ne sklapaju ugovori o dodjeli potpore osim u slučaju sufinanciranja većih sportskih objekata. U ostalim slučajevima podnositelj zahtjeva obvezuje se na poštivanje Smjernica koje uređuju prava i obveze u procesu dodjele potpora. Kada Gradska skupština donese odluku o prihvaćanju zahtjeva za dodjelom potpore, Magistarski odjel 51 - Ured za sport daje nalog za isplatu sredstava.

Mišljenje: U Gradu Zagrebu i Gradu Beču osiguran je okvir temeljem kojeg se proračunska sredstva usmjeravaju na razvoj sporta na svim razinama društva (profesionalni sport, amaterski sport, sport u obrazovnim institucijama i sport za građane starije životne dobi). Procedura donošenja Programa javnih potreba u sportu Grada Zagreba je, u odnosu na proceduru provedbe programa sportskih aktivnosti Grada Beča, kompleksnija i zahtjeva angažman značajnog broja službenika gradske uprave i Sportske zajednice. Uvažavajući razlike u regulativi koju gradske uprave primjenjuju i učestalu promjenu propisa u Republici Hrvatskoj, revizorski tim je mišljenja da procedura donošenja Programa javnih potreba u sportu osigurava transparentnu dodjelu i kontrolu namjenskog korištenja proračunskih sredstava. Zajedničke karakteristike procesa dodjele sredstava za sport u Zagrebu i Beču su: procedure i pravila utvrđena za dodjelu sredstava za provođenje sportskih programa, uspostavljeni sustav unutarnjih kontrola kojima se osigurava financiranje sukladno kriterijima, adekvatno dokumentirane faze raspodjele sredstava. Unapređenje sustava kontrola moguće je u dijelu definiranja kriterija za raspodjelu sredstava za velike sportske priredbe radi osiguravanja adekvatne podloge za raspodjelu sredstava.

Preporuka: Propisati kriterije za raspodjelu proračunskih sredstava za velike sportske priredbe. 
Kontrolni cilj: Osigurati korištenje sredstava u skladu s Programom javnih potreba u sportu Grada Zagreba

\section{Nalaz 4. Kontrola namjenskog korištenja sredstava u Gradu Zagrebu}

Sredstva koja Gradski ured za obrazovanje, kulturu i sport izravno doznačuje programskim korisnicima isplaćuju se na temelju ugovora. Korisnici sredstava dostavljaju izvješća uz koja prilažu dokaze o namjenskom korištenju sredstava. Pregledom predmeta utvrđeno je da izvješća nisu potpuna, odnosno ne sadrže sve elemente koji su propisani ugovorom zbog čega je potrebno ojačati kontrole u procesu izvještavanja. U Gradskom uredu za obrazovanje, kulturu i sport proces od predaje zahtjeva do kontrole namjenskog korištenja sredstava nije informatički objedinjen što otežava praćenje namjenskog utroška sredstava.

Sportskoj zajednici Grada Zagreba godišnji iznos planiranih sredstava doznačuju se u 12 obroka. Istovjetna procedura primjenjuje se na saveze i klubove. Testiranjem je potvrđeno da se procedura mjesečnog doznačivanja sredstava dosljedno primjenjuje. Kontrola namjenskog korištenja sredstava u Sportskoj zajednici Grada Zagreba provodi se kroz web aplikaciju u koju korisnici sredstava unose dokaze o namjenskom korištenju sredstava. Aplikacija omogućava generiranje izvješća koja se dostavljaju Gradskom uredu za obrazovanje, kulturu i sport.

\section{Nalaz 4. Kontrola namjenskog utroška sredstava u Gradu Beču}

Kontrolu obračuna i namjenskog utroška sredstava obavlja Magistratski odjel 51 - Ured za sport. Pri tome se uvijek poštuje načelo „četiri oka“. Rezultati kontrole se unose u protokol elektroničke obrade podataka. Namjenski utrošak sredstava dokazuje se računom, bankovnim izvatkom ili potvrdom o isplati ukoliko je plaćeno putem internetskog bankarstva. Neprihvatljivi troškovi su: dopinški pripravci, odnosno dodaci prehrani, putni troškovi, računi koje nisu u skladu sa Zakonom o porezu na dodanu vrijednost, troškovi posluživanja jela i pića izvan priredbe i alkoholna pića. U slučaju financiranja sportskih priredaba korisnici podnose popis potvrda svih primitaka i izdataka. Magistratski odjel 51 kontrolira potvrde po vlastitom izboru do visine iznosa dodijeljenih sredstava.

Mišljenje: U Gradu Zagrebu dosljedna primjena procedure mjesečnog doznačivanja sredstava osigurava preduvjete za realizaciju zajedničkih programa sporta. Korištenje informatičkog sustava (web aplikacije) u svrhu kontrole namjenskog korištenja sredstava u kojoj korisnici samostalno unose dokaze o namjenskom korištenju i mogućnost generiranja izvješća adekvatno je rješenje koje omogućava racionalno korištenje administrativnih resursa Sportske zajednice. Izostanak automatske obrade podataka i kontrole namjenskog korištenja sredstava koja Gradski ured za obrazovanje, kulturu i sport isplaćuje korisnicima na temelju ugovora, zahtjeva značajan angažman službenika koji utrošak i realizaciju sportskih aktivnosti prate kroz izvješća korisnika. Implementacija jedinstvenog informatičkog rješenja za cjelokupan proces raspodjele i kontrole namjenskog korištenja sredstava za provedbu programa javnih potreba u sportu omogućila smanjenja administrativnih troškova u korist programskih troškova. Povezivanje podataka Gradskog ureda za obrazovanje, kulturu i sport i podataka Sportske zajednice Grada Zagreba unaprijedilo bi proces vrednovanja razvojnih i drugih programa u području sporta koji se financiraju proračunskim sredstvima na svim razinama i umanjilo nastanak rizika isplate višestruke potpore.

Kontrola namjenskog korištenja sredstava temeljem vjerodostojne dokumentacije po načelu „četiri oka“ i elektronička obrada podataka rezultata kontrole obračuna i namjenskog utroška sredstava u Gradu Beču je adekvatna. Propisane vrste neprihvatljivih troškova povećavaju transparentnost procesa dodjele sredstava i omogućavaju jednostavno detektiranje vrste prihvatljivih troškova. Uspostavljena procedura kontrole sredstava za sportske priredbe koja zahtjeva dostavu popisa potvrda svih primitaka i izdataka adekvatna je podloga za donošenje odluka o visini proračunskih sredstava koja će biti dodijeljena za realizaciju sportskih događaja.

Implementacija procedure Grada Beča u proces isplate i kontrole namjenskog korištenja sredstava za velike sportske priredbe u Gradu Zagrebu povećala bi razinu transparentnosti visine dodijeljenih sredstava i omogućila vrednovanje velikih sportskih priredbi temeljem mjerljivih kriterija.

Preporuka: Implementirati jedinstveno informatičko rješenje za proces raspodjele i kontrole namjenskog korištenja sredstava za provedbu Programa javnih potreba u sportu s ciljem smanjenja administrativnih troškova u korist programskih troškova.

\section{Kontrolni cilj: Osigurati pravovremeno i potpuno izvještavanje o realizaciji Programa javnih potreba u sportu Grada Zagreba}

Nalaz 5. Izvještavanje o realizaciji programa u Grada Zagreba

U Gradskom uredu za obrazovanje, kulturu i sport i Sportskoj zajednici Grada Zagreba uspostavljena je procedura izvještavanja o izvršenju Programa javnih potpora u sportu. Polugodišnja i godišnja izvješća o realizaciji Programa javnih potreba u sportu dostavljaju se na usvajanje Gradskoj skupštini Grada Zagreba. U izvješćima je analitički prikazana realizacija po programskim područjima i korisnicima koji su financirani kroz Program javnih potreba u sportu. Gradska skupština Grada Zagreba prihvatila je Izvješće o izvršenju Programa javnih potpora u sportu Grada Zagreba za 2013. godinu.

\section{Nalaz 5. Izvještavanje o realizaciji programa u Gradu Beču}

U Gradu Beču o realizaciji pojedine sportske aktivnosti podaci se mogu dobiti uvidom u web aplikaciju u kojoj su vidljivi podaci o zahtjevima za dodjelu potpore, odluka Gradske skupštine o visini dodijeljenih sredstava, isplata sredstava, obračunska dokumentacija i kontrola obračuna. U aplikaciji su podaci o vrsti potpora (između ostalog naziv subjekta i ime osobe za kontakt podnositelja zahtjeva za dodjelu potpore, vrsta sporta i potpore, trajanje projekta, visina odobrenih sredstava te rokovi za obračun).

Mišljenje: U Gradu Zagrebu uspostavljena je procedura izvještavanja o realizaciji Programa javnih potreba u sportu. Uvođenje aplikativnog rješenja za praćenje procesa financiranja sporta u Gradu Zagrebu unaprijedit će proces izvje- 
štavanja i osigurati odgovornim osobama Grada ažurne i cjelovite informacije.

U Gradu Beču procedura izvještavanja o realizaciji sportskih aktivnosti osigurana je putem aplikativnog rješenja koje osigurava ažurne podatke o realizaciji pojedine sportske aktivnosti.

\section{REZIME}

Horizontalna revizija procesa financiranja sporta u Gradu Zagrebu i Gradu Beču u pravilu je potvrdila da je uspostavljeni sustav unutarnjih kontrola adekvatan i djelotvoran te da se dosljedno primljenjuje. Procedura donošenja Programa javnih potreba u sportu Grada Zagreba i zastupljenost svih vrsta sportova u Programu ukazuje na provođenje politike daljnjeg populariziranja svih vrsta sportova i unapređenja kvalitete sportskih aktivnosti. U proces financiranja sporta $\mathrm{u}$ Gradu Zagrebu trebalo bi ugraditi dodatne kontrole za koje je revizorski tim Grada Beča dao pozitivno stručno mišljenje i za koje je u praksi potvrđena funkcionalnost i adekvatnost, koje su usmjerene na smanjivanje operativnih troškova i usmjeravanje sredstava u rad sportskih udruga. U Republici Hrvatskoj su promjene Zakona o porezu na dohodak u 2014. godini izravno utjecale na visinu prihoda Proračuna Grada Zagreba za 2015. godinu. Promjena porezne regulative negativno je utjecala na sve aktivnosti Grada Zagreba. Za Program javnih potreba u sportu Grada Zagreba u 2015. godini osigurano je 20,44 \% manje proračunskih sredstava u odnosu na 2014. godinu što je pokazatelj da će i sustav financiranja sporta biti izložen promjenama.

\section{LITERATURA}

Ministarstvo financija. (2010). Priručnik za unutarnje revizore, verzija 4.0. Datum posjete 03.10.2015. Dostupno na http:// www.mfin.hr/adminmax/docs/Prirucnik\%20za\%20unutarnje\%20revizore\%20v.4.0.30-11-2010.pdf

Narodne novine. (2001). Zakon o lokalnoj, područnoj (regionalnoj) samoupravi. Datum posjete 03.10.2015. Dostupno na http:// narodne-novine.nn.hr/clanci/sluzbeni/2001_04_33_569.html

Narodne novine. (2006). Zakon o sportu. Datum posjete 05.10.2015. Dostupno na http://narodne-novine.nn.hr/clanci/sluzbeni/2006_06_71_1704.html

Narodne novine. (2006). Zakon o sustavu unutarnjih financijskih kontrola u javnom sektoru. Datum posjete 28.10.2015. Dostupno na http://narodne-novine.nn.hr/clanci/sluzbeni/2006_12_141_3188.html

Narodne novine. (2015). Zakon o sustavu unutarnjih kontrola u javnom sektoru. Datum posjete 29.10.2015. Dostupno na http://narodne-novine.nn.hr/clanci/sluzbeni/2015_07_78_1492.html

Narodne novine. (2014). Zakon o udrugama. Datum posjete 03.10.2015. Dostupno na http://narodne-novine.nn.hr/ clanci/sluzbeni/2014_06_74_1390.html

Službeni glasnik Grada Zagreba. (2013). Plan sredstava za sufinanciranje programa sporta u Gradu Zagrebu za 2013. godinu. Datum posjete 29.10.2015. Dostupno na http://www1.zagreb. $\mathrm{hr} / \mathrm{slglasnik.nsf}$

Službeni glasnik Grada Zagreba. (2013). Program javnih potreba u sportu Grada Zagreba za 2013. godinu. Datum posjete 29.10.2015. Dostupno na http://wwwl.zagreb.hr/slglasnik.nsf

\section{AUDIT OF SPORT FUNDING - HORIZONTAL AUDIT FOR THE CITY OF ZAGREB AND VIENNA}

\begin{abstract}
:
The city control office in Zagreb and the control office of the city of Vienna have performed the horizontal audit of sport funding for the purpose of assessing the existing internal control system, providing expert opinion and giving recommendations for further improvements. The audit was conducted based on the methodology for carrying out internal audit of the Ministry of Finance. The common characteristics of the process of sport funding in Zagreb and Vienna include the following: procedures and rules for granting funds for conducting sports programs, internal control system that ensures transparent allocation of resources and documented phases of resource allocation. The city of Zagreb offers the opportunity for the improvement of the internal control system in the processes of allocation of funds for major sport events and monitoring of the use of funds for such sports programs. The holders of the revised process are suggested to prescribe the criteria for the allocation of funds for major sport events and implementation of unique IT solutions for distribution and control of spending of budgetary funds for the implementation of public programs.
\end{abstract}

\section{Key words:}

internal control system, public needs in sport, spending of budgetary funds for designated purposes. 